\title{
Photosynthetic efficiency, gas exchange and yield of castor bean intercropped with peanut in semiarid Brazil
}

\author{
Wellison F. Dutra ${ }^{1}$, Alberto S. de Melo ${ }^{2}$, Alexson F. Dutra ${ }^{1}$, \\ Marcos E. B. Brito ${ }^{3}$, Luanna M. B. Filgueiras ${ }^{1}$ \& Carlos H. S. G. Meneses ${ }^{2}$ \\ ${ }^{1}$ Universidade Estadual da Paraíba/Programa de Pós-graduação em Ciências Agrárias. Campina Grande, PB. E-mail: wellison_eu@hotmail.com; \\ alexsonbrejo@hotmail.com; luannabeserra-uepb@hotmail.com \\ ${ }^{2}$ Universidade Estadual da Paraíba/Departamento de Biologia/Núcleo de Pesquisa em Ciências Agrárias. Campina Grande, PB. E-mail: alberto@uepb.edu.br \\ (Corresponding author); carlos@ccaa.uepb.edu.br \\ ${ }^{3}$ Universidade Federal de Campina Grande/Centro de Ciências e Tecnologia Agroalimentar/Unidade Acadêmica de Ciências Agrárias. Pombal, PB. \\ E-mail: marcoseric@ccta.ufcg.edu.br
}

\section{Key words:}

chlorophyll fluorescence

photosynthesis

Ricinus communis L. yield

\begin{abstract}
A B S T R A C T
To evaluate the photosynthetic efficiency, gas exchange and yield of castor bean intercropped with peanut under Brazilian semiarid conditions, a field experiment was set up with six treatments and four replicates arranged in a randomized block design. The experiment consisted of the cultivation of castor bean 'BRS Energia' in a monocrop system and intercropped with peanut 'BR 1'. One treatment was formed by monocropped castor bean and the others by the castor bean intercropped with peanut with different intercrop establishment times, i.e. peanut sowing times $(0,10,15,20$ and 25 days after castor bean sowing). The castor bean photosynthetic and carboxylation efficiencies were higher in the intercrop system with a 25 -day interval between sowings. Peanut sowing at 0 to 10 days after castor bean sowing in the intercropped system affected the photochemical efficiency of the latter, which resulted in its yield reduction. Larger intervals between sowing of peanut 'BR-1' and of the main crop increased castor bean yield in the intercrop system.
\end{abstract}

\section{Palavras-chave:}

fluorescência da clorofila fotossíntese

Ricinus communis L. produtividade

\section{Eficiência fotossintética, trocas gasosas e produção da mamoneira consorciada com amendoinzeiro no semiárido brasileiro}

\section{R E S U M O}

Com objetivo de avaliar a eficiência fotossintética, as trocas gasosas e a produção da mamoneira consorciada com amendoinzeiro em condições do Semiárido brasileiro, realizou-se um estudo em condições de campo com seis tratamentos e quatro repetições, organizados no delineamento em blocos ao acaso, constituídos do cultivo da mamoneira 'BRS Energia' em sistema de monocultivo e consorciada com amendoim 'BR 1'. Um tratamento foi formado pela mamona em monocultura e os demais pelo consórcio de mamona e amendoim, diferindo a época de estabelecimento da consorciação, ou seja, em diferentes épocas de semeadura do amendoim $(0,10,15,20$ e 25 dias após a mamona). A eficiência fotossintética e de carboxilação da mamoneira foi incrementada no consórcio com 25 dias de intervalo entre as semeaduras. $\mathrm{O}$ amendoim semeado entre 0 e 10 dias no consórcio afetou a eficiência fotoquímica da mamona, o que resultou em redução dos componentes produtivos. Os maiores intervalos de semeadura do amendoim 'BR-1', em relação à cultura principal, possibilitam alcançar melhores rendimentos de grãos de mamona no sistema consorciado. 


\section{INTRODUCTION}

Intercropping the simultaneous cultivation of different plant species in the same area is a widely used agricultural practice in tropical regions. This system improves plant productivity and, consequently, leads to high economic stability in rural properties (Lithourgidis et al., 2011; Pinto et al., 2013). Studies on the intercropping of castor bean with crop species such as sorghum, cowpea, common bean, sesame, and sunflower have evidenced yield advantages of intercropping over monocropping (Teixeira et al., 2012; Cardoso et al., 2013; Pinto et al., 2013). These studies indicate that intercrops do not compete for environmental resources over time across a given area because of the differential competitive abilities of the plant species used. Thus, intercropping efficiency is directly associated with the selection of crops with different competitive abilities and with the time of intercropping establishment.

In Northeastern Brazil, especially in its semiarid region, water is scarce and rainfall distribution does not adequately meet the water requirements of crops, which often leads to morphophysiological disturbances and consequent losses in plant production (Suassuna et al., 2011; Ferraz et al., 2012).

According to Lithourgidis et al. (2011), even though gas exchange measurements are important to determine the photosynthetic rate of plants under water stress, they may not evaluate the deleterious effects on chloroplasts as efficiently as they do the effects on photosynthetic efficiency. However, even with the significant production of castor bean in Northeastern Brazil, no reports exist on physiological variations in intercropping systems in semiarid-climate regions.

Thus, it was aimed to evaluate the photosynthetic efficiency, gas exchange and yield of castor bean intercropped with peanut in semiarid of Brazil.

\section{Material ANd Methods}

The study was carried out from March to August 2014, at the Experimental Farm of Fruit Production and Plant Ecophysiology, Center for Human and Agricultural Sciences, Paraíba State University, Catolé do Rocha city, Paraíba State, Northeastern Brazil, situated at 6 $20^{\prime} 38^{\prime \prime} \mathrm{S}$ and $37^{\circ} 44^{\prime} 48^{\prime \prime} \mathrm{W}$, at an altitude of $250 \mathrm{~m}$ above sea level. According to Köppen's classification, the climate in the region is type BSw'h', i.e., hot dry semiarid, with a mean annual rainfall of $870 \mathrm{~mm}$, mean annual temperature of $27^{\circ} \mathrm{C}$, and a rainy season concentrated between February and April.

The soil in the experimental area is classified as Eutrophic Fluvic Neosol, having sandy texture (EMBRAPA, 2013) and has the following physicochemical characteristics: $\mathrm{pH}\left(\mathrm{H}_{2} \mathrm{O}\right)=$ 6.84, $\mathrm{P}($ Mehlich $)=49 \mathrm{mg} \mathrm{dm}^{-3}, \mathrm{~K}=280 \mathrm{mg} \mathrm{dm}^{-3}, \mathrm{OM}=13.4$ $\mathrm{g} \mathrm{dm}^{-3}, \mathrm{Ca}=5.25 \mathrm{cmol}_{\mathrm{c}} \mathrm{dm}^{-3}, \mathrm{Mg}=1.15 \mathrm{cmol}_{\mathrm{c}} \mathrm{dm}^{-3}, \mathrm{Na}=64$ $\mathrm{mg} \mathrm{dm}^{-3}, \mathrm{Fe}=59.69 \mathrm{mg} \mathrm{dm}^{-3}, \mathrm{Zn}=4.05 \mathrm{mg} \mathrm{dm}^{-3}, \mathrm{Cu}=3.83 \mathrm{mg}$ $\mathrm{dm}^{-3}, \mathrm{Mn}=53.98 \mathrm{mg} \mathrm{dm}^{-3}, \mathrm{~B}=6.45 \mathrm{mg} \mathrm{dm}^{-3}, \mathrm{Al}=0.0 \mathrm{cmol}_{\mathrm{c}}$ $\mathrm{dm}^{-3}$, sand $=773.7 \mathrm{~g} \mathrm{~kg}^{-1}$, silt $=168.3 \mathrm{~g} \mathrm{~kg}^{-1}$, and clay $=58 \mathrm{~g} \mathrm{~kg}^{-1}$.

The study involved the cultivation of castor bean 'BRS Energia' in two planting systems: monocropping and intercropping with peanut 'BR-1'. Both cultivars, whose main characteristics are an early cycle and high yield, were developed by Embrapa Algodão. Treatments consisted of monocropped castor bean (T1) and castor bean intercropped with peanut, with peanut sowed at 0 (T2), 10 (T3), 15 (T4), 20 (T5), and 25 days (T6) after castor bean. Treatments were arranged in four randomized blocks. The experimental unit had $5.0 \mathrm{~m}$ rows, with five castor bean plants spaced $2.0 \times 0.5 \mathrm{~m}$ from one another, associated or not with five rows of peanut plants spaced 2.0 $\times 0.2 \mathrm{~m}$ from one another. The useful area in both growing systems comprised the central lines of the experimental plot.

Soil was prepared conventionally by plowing and tilling to 0.30 and $0.15 \mathrm{~m}$ depths, respectively. Seeds were sowed manually. The amount of fertilizer used was based on the soil chemical analysis: urea $(45 \% \mathrm{~N})$, single superphosphate $(20 \%$ $\left.\mathrm{P}_{2} \mathrm{O}_{5}\right)$, and potassium chloride $\left(60 \% \mathrm{~K}_{2} \mathrm{O}\right)$, as recommended by Ribeiro et al. (1999). Nitrogen was not applied to peanut plants.

It is worth mentioning that the observed total rainfall (221 $\mathrm{mm}$ ) was below the expected for the experimental period, as the accumulated precipitation for the region normally ranges around $350 \mathrm{~mm}$ during the months of the experiment.

Chlorophyll a fluorescence was quantified 66 days after emergence (DAE) in both cropping systems, while gas exchange was assessed 73 DAE. In the morning (08:00-10:00 $A M)$, readings were taken on the third leaf from the apex of two central plants in each plot.

To quantify chlorophyll a fluorescence, leaves were dark adapted for $30 \mathrm{~min}$. Soon after, the initial (Fo), maximum (Fm), and variable fluorescence $(\mathrm{Fv})$ and the quantum efficiency of photosystem II (Fv/Fm) were measured using a portable Hansatech fluorometer (Suassuna et al., 2011).

For gas exchange assessment, a portable infrared gas analyzer (IRGA) LCpro+ was used. The following parameters were quantified: stomatal conductance (gs) $\left(\mathrm{mol} \mathrm{H}_{2} \mathrm{O} \mathrm{m}^{-2} \mathrm{~s}^{-1}\right)$, transpiration (E) $\left(\mathrm{mmol} \mathrm{H}_{2} \mathrm{O} \mathrm{m}^{-2} \mathrm{~s}^{-1}\right)$, net photosynthesis (A) $\left(\mu \mathrm{mol} \mathrm{m} \mathrm{m}^{-2} \mathrm{~s}^{-1}\right)$, internal $\mathrm{CO}_{2}$ concentration $(\mathrm{Ci})\left(\mu \mathrm{mol} \mathrm{m}{ }^{-2} \mathrm{~s}^{-1}\right)$, instantaneous carboxylation efficiency (A/Ci) $\left[\left(\mu \mathrm{mol} \mathrm{m}{ }^{-2} \mathrm{~s}^{-1}\right) /\right.$ $\left.\left(\mu \mathrm{mol} \mathrm{m} \mathrm{m}^{-1}\right)\right]$, and instantaneous water use efficiency (IWUE) (A/E) $\left[\left(\mu \mathrm{mol} \mathrm{m}^{-2} \mathrm{~s}^{-1}\right) /\left(\mathrm{mmol} \mathrm{H}_{2} \mathrm{O} \mathrm{m}^{-2} \mathrm{~s}^{-1}\right)\right]$ (Melo et al., 2009; Ferraz et al., 2012).

To quantify castor bean yield $\left(\mathrm{kg} \mathrm{ha}^{-1}\right)$, a manual harvesting was performed $130 \mathrm{DAE}$, after complete pod maturation, and mass of the produced seeds was determined using a semianalytical balance ( $0.1 \mathrm{~g}$ precision).

Data were subjected to analysis of variance by $\mathrm{F}$ test ( $\mathrm{p}$ $<0.05)$. Means were compared by Tukey test $(\alpha=5 \%)$ and analyzed by Pearson's correlation. All analyses were conducted using software SAEG 9.1.

\section{Results AND Discussion}

Fluorescence evaluation showed the highest Fo (368.62), Fm (1800.87) and Fv (1430.5) values in monocropped castor bean (T1). The analysis revealed an increase in 12.51, 12.23, and $14.18 \%$ in relation to the lowest values found, which were detected in the intercropping system in which peanut was sowed 15 days later $(\mathrm{T} 4)(\mathrm{Fo}=327.62)$ and in that in which the castor bean and peanut were both sowed on the same day (T2) $(\mathrm{Fm}=1604.62$ and $\mathrm{Fv}=1252.75)($ Figures $1 \mathrm{~A}, 1 \mathrm{~B}$, and $1 \mathrm{C})$. 
A.
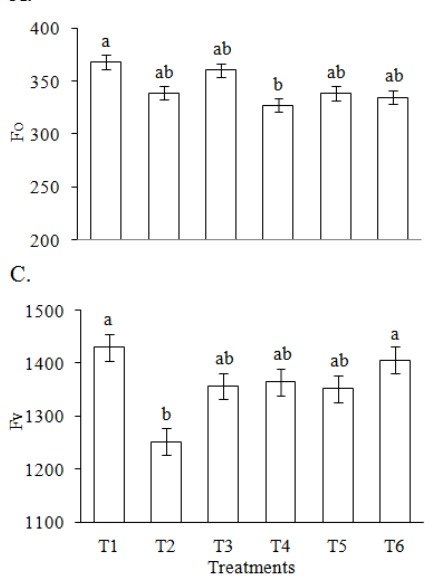

B.
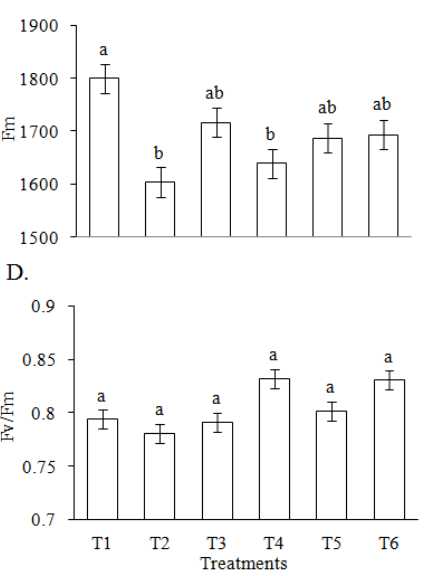

Different letters on bars indicate significant differences between treatments according to Tukey test $(P<0.05)$. Vertical bars correspond to standard error

Figure 1. Initial fluorescence (Fo) (A), maximum fluorescence $(\mathrm{Fm})(\mathrm{B})$, variable fluorescence $(\mathrm{Fv})(\mathrm{C})$ and quantum efficiency of photosystem II (Fv/Fm) (D) of castor bean in monocropped and intercropped system with peanut at different sowing dates

On the other hand, the highest Fv value (1407.0) was found in castor bean plants intercropped with peanut ones sown 25 days later (T6). Such value had a $12.31 \%$ increase in comparison with the one observed in T2 plants (Figure 1C). There was no significant difference $(\mathrm{p}>0.05)$ in the Fv/Fm among treatments. However, the higher Fv/Fm values were observed in peanut plants sowed 15 (T4), 20 (T5) and 25 (T6) days after the castor bean (Figure 1D). The castor bean has a fast initial growth and is more competitive for the resources available in the environment; it was therefore not affected by the late-sown peanut. This fact allowed for the normal development of castor bean plants, which was similar to the development observed in monocropped plants of this species. This probably explains the high Fv and Fv/Fm values observed in T6 plants compared to the other intercropping treatments.

The high Fo values observed in monocropped castor bean may be related to the drought that occurred during the experimental period. Such drought might have led to disturbances in the reaction center of PSII and/or to reductions in the ability of photosynthetic pigments to transfer energy to the PSII reaction center (Suassuna et al., 2011). The decreased Fo observed in castor bean intercropped with longer

intervals between sowings (T4, T5, and T6) may indicate the development of protective mechanisms to the photosynthetic apparatus. This is a common response to water stress, under which plants are capable of regulating the activity of the PSII reaction center and dissipate energy. This is demonstrated by the negative correlation between Fo and Fv/Fm $\left(\mathrm{R}=-0.622^{\star *}\right)$ and the positive correlation between Fo and Fm $\left(\mathrm{R}=0.615^{\star *}\right)$ (Table 1).

The reduction in the Fm observed in castor bean plants intercropped with no sowing interval (Figure 1B) caused a decrease in photochemical reactions and the consequent depletion in the capacity of $\mathrm{CO}_{2}$ assimilation at the biochemical stage of photosynthesis (Figure 2C). Such behavior is evidenced by the existence of a positive correlation between Fm and Fv ( R $=0.794^{* *}$ ), as shown in Table 1 . It should be observed that an increased Fm signalizes an increased quinone photoreduction efficiency, which in turn indicates an optimal PSII performance in the thylakoid membrane, thus directly reflecting an optimized electron flow between the photosystems (Silva et al., 2006; Ferraz et al., 2014). In addition, the higher the Fv, the greater will be the ability of pigments to transfer energy of expelled electrons to form the NADPH reducing agent, ATP, and ferredoxin reductase (FdR), and therefore the greater will be the $\mathrm{CO}_{2}$ assimilation capacity of the plant.

However, in this research, increased photochemical efficiency coupled to a significant correlation between Fv and $\mathrm{Fv} / \mathrm{Fm}\left(\mathrm{R}=0.505^{\star *}\right)$ did not result in an increased $\mathrm{A}$ in the castor bean (Table 1). On the other hand, even with no increase in net photosynthesis plants with higher yields showed highest Fv, which could be explained by the existence of a positive correlation between $\mathrm{Fv}$ and yield in the castor bean $(\mathrm{R}=$ $0.527^{\star *}$ ) (Table 1$)$.

Fluorescence variables such as the Fv/Fm ratio have been used to assess biotic and abiotic stresses, mainly due to the detection of damage to the operation of PSII, as demonstrated by Dias \& Marenco (2007). These researchers reported that in healthy vascular plants the $\mathrm{Fv} / \mathrm{Fm}$ ratio ranges around $0.832 \pm$ 0.004 . However, plants subjected to other treatments showed values above the photochemical limit that could cause damage to PSII, which is 0.75 (Suassuna et al., 2011). Generally, the $\mathrm{Fv} / \mathrm{Fm}$ ratio is affected mainly by variations in maximum fluorescence. In the present study, variations in quantum

Table 1. Correlation matrix among the variables initial fluorescence (Fo), maximum fluorescence (Fm), variable fluorescence (Fv), quantum efficiency of photosystem II (Fv/Fm), stomatal conductance (Gs), transpiration (E), net photosynthesis (A), carbon internal concentration (Ci), instantaneous carboxylation efficiency (A/Ci), instantaneous water use efficiency (IWUE) and yield of castor bean

\begin{tabular}{|c|c|c|c|c|c|c|c|c|c|c|c|}
\hline & Fo & $\mathrm{Fm}$ & Fv & $\mathrm{Fv} / \mathrm{Fm}$ & gs & $E$ & A & $\mathrm{Ci}$ & $\overline{\mathrm{A} / \mathrm{Ci}}$ & IWUE & Yield \\
\hline Fo & - & 0.615 & 0.146 & -0.622 & -0.264 & 0.430 & -0.154 & -0.121 & -0.093 & -0.317 & -0.043 \\
\hline $\mathrm{Fm}$ & $\star *$ & - & 0.794 & -0.124 & -0.076 & 0.350 & -0.091 & -0.345 & 0.190 & -0.083 & 0.402 \\
\hline Fv & ns & $\star \star$ & - & 0.505 & 0.125 & 0.201 & 0.152 & -0.342 & -0.291 & 0.036 & 0.527 \\
\hline $\mathrm{Fv} / \mathrm{Fm}$ & $\star \star$ & ns & ** & - & 0.318 & -0.172 & 0.123 & -0.065 & 0.162 & 0.186 & 0.297 \\
\hline Gs & ns & ns & ns & ns & - & -0.117 & 0.469 & -0.444 & 0.563 & 0.407 & 0.279 \\
\hline $\mathrm{E}$ & * & * & ns & ns & ns & - & -0.302 & -0.379 & -0.120 & -0.684 & 0.084 \\
\hline A & ns & ns & ns & ns & $\star *$ & ns & - & -0.207 & 0.880 & 0.899 & 0.579 \\
\hline $\mathrm{Ci}$ & ns & * & ns & ns & * & * & ns & - & -0.604 & 0.015 & -0.374 \\
\hline $\mathrm{A} / \mathrm{Ci}$ & ns & ns & ns & ns & $\star \star$ & ns & $\star \star$ & $\star \star$ & - & 0.721 & 0.604 \\
\hline IWUE & ns & ns & ns & ns & * & $\star *$ & $\star *$ & ns & $\star *$ & - & 0.404 \\
\hline Yield & ns & * & $\star \star$ & ns & ns & ns & $\star \star$ & * & $\star \star$ & * & - \\
\hline
\end{tabular}

$\mathrm{ns},{ }^{* *},{ }^{*}$ Not significant and significant at 0.01 and 0.05 respectively 
efficiency had a positive correlation with fluctuations in Fv $\left(\mathrm{R}=0.505^{\star *}\right)$ (Table 1$)$.

The highest gs $\left(0.505 \mathrm{~mol} \mathrm{H}_{2} \mathrm{O} \mathrm{m}^{-2} \mathrm{~s}^{-1}\right)$ was observed in the intercropping system with peanut sowed 10 days after the castor bean, in which plants showed a $38.36 \%$ increase in relation to the intercropping system with no interval between sowings, in which plants showed the lowest gs $\left(0.365 \mathrm{~mol} \mathrm{H}_{2} \mathrm{O} \mathrm{m}^{-2} \mathrm{~s}^{-1}\right)$ (Figure 2A). The intercropping systems with peanut sown 10 and 25 days after the castor bean provided an average increase of $28.03 \%$ in stomatal conductance in relation to the monocrop. On the other hand, no statistical difference $(p>0.05)$ between the monocrop and the intercropping system with no interval between sowings was observed. Unlike gs, E was influenced neither by the cropping system nor by the time of peanut sowing in relation to castor bean sowing $(\mathrm{p}>0.05)$ (Figure $2 \mathrm{~B})$.

The intercropping system with peanut sown 20 and 25 days after the castor bean (T5 and T6, respectively) increased A, A/ $\mathrm{Ci}$, and IWUE in the latter species (Figures $2 \mathrm{C}, 2 \mathrm{D}$, and $2 \mathrm{E}$ ). The lowest values of $\mathrm{A}$ and $\mathrm{A} / \mathrm{Ci}\left(22.19 \mu \mathrm{mol} \mathrm{m}^{-2} \mathrm{~s}^{-1}\right.$ and 0.105 $\left(\mu \mathrm{mol} \mathrm{m} \mathrm{m}^{-2} \mathrm{~s}^{-1}\right) /\left(\mu \mathrm{mol} \mathrm{m} \mathrm{m}^{-2} \mathrm{~s}^{-1}\right)$, respectively) were observed in the intercrop with no interval between sowings (T2), differing in 21.76 and $23.8 \%$ from the maximum values $\left(27.02 \mu \mathrm{mol} \mathrm{m} \mathrm{m}^{-2}\right.$ $\mathrm{s}^{-1}$ and $0.13\left(\mu \mathrm{mol} \mathrm{m} \mathrm{m}^{-2} \mathrm{~s}^{-1}\right) /\left(\mu \mathrm{mol} \mathrm{m} \mathrm{m}^{-2} \mathrm{~s}^{-1}\right)$, respectively), which were found in T4 and T3, respectively. Furthermore, a 20-day interval between sowings (T5) increased A and IWUE in 17.47 and $28.36 \%$ respectively in the castor bean in relation to the monocrop (T1). Similar behavior was observed in the A/Ci of plants from the intercropping system with no interval between sowings (T2), which showed a $18.18 \%$ increase in relation to monocropped (T1) plants.
A.

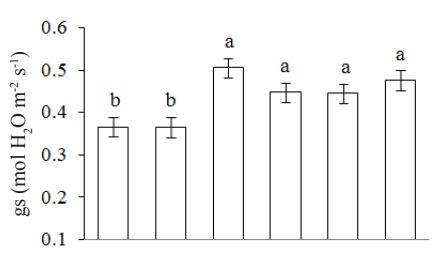

C.

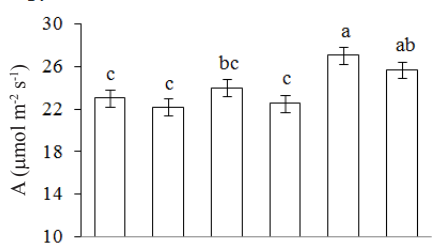

E.

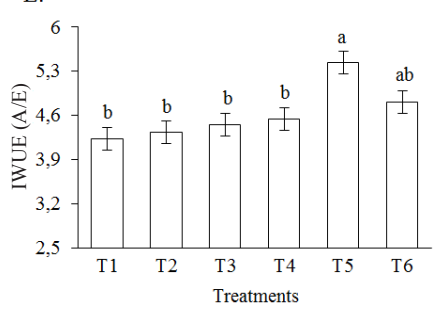

B.

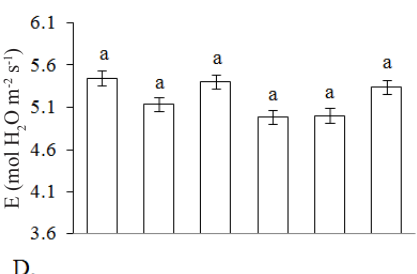

D.

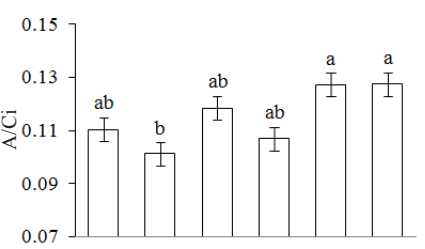

F.

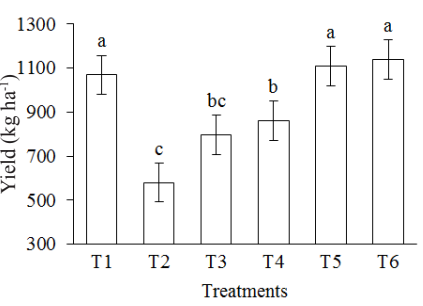

Different letters on bars indicate significant differences between treatments according to Tukey test $(P<0.05)$. Vertical bars correspond to standard error

Figure 2. Stomatal conductance (gs) (A), transpiration (E) (B), net photosynthesis $(A)(C)$, instantaneous carboxylation efficiency $(\mathrm{A} / \mathrm{Ci})(\mathrm{D})$, instantaneous water use efficiency (IWUE) (E) and yield (F) of castor bean in monocropped and intercropped with peanut at different sowing dates
Stomatal conductance regulates gas exchange and therefore is directly related to photosynthesis and plant yield (Paiva et al., 2005). In this research, late intercropping establishment provided higher gs values than those observed in both the monocropping and intercropping with no interval between sowings (T2), which contributed increasing A in castor bean plants $\left(R=0.469^{* *}\right)$ (Table 1$)$ with no significant influence on E. That explains the higher IWUE observed in such plants, which indicates the normal functioning of the photosynthetic apparatus in castor bean plants intercropped with peanut with no interval between sowings. Furthermore, the low A observed in intercropped castor bean sown simultaneously with peanut can be explained by an increased competition for soil water. This may be related to differences between the growth rates of the two species, which might cause a decline in gs and the consequent reduction in A due to the limited inflow of $\mathrm{CO}_{2}$ to the mesophyll. These results match the unaltered $\mathrm{E}$ and justify the existence of a linear correlation between gs and IWUE (R $\left.=0.407^{\star}\right)$ (Table 1$)$.

The increase in $\mathrm{A} / \mathrm{Ci}$ observed in intercropped castor bean was due to an increase in $\mathrm{CO}_{2}$ assimilation rate, as evidenced by the strong correlation between these variables $\left(\mathrm{R}=0.880^{* *}\right)$ (Table 1). It was also found a significant correlation between A/ $\mathrm{Ci}$ and gs $\left(\mathrm{R}=0.563^{* *}\right)$, which suggests an increase demand for inflow of $\mathrm{CO}_{2}$ to the mesophyll in order to maintain A levels. Thus, the A/Ci has strong relationship with intracellular $\mathrm{CO}_{2}$ concentration and $\mathrm{CO}_{2}$ assimilation rate (Machado et al., 2005).

The observed interdependence between stomatal conductance and $\mathrm{CO}_{2}$ assimilation rate is justified by the fact that during gas exchange $\mathrm{CO}_{2}$, absorption during gas exchange competes with the water loss to the atmosphere, which is associated with IWUE. The IWUE expresses the relationship between $\mathrm{A}$ and $\mathrm{E}$, whose observed values are related to the amount of carbon fixed per unit of water lost. This process is influenced by environmental conditions, including water shortage (Jaimez et al., 2005; Shimazaki et al., 2007; Melo et al., 2009).

Under water shortage conditions, intercropping increased the IWUE of castor bean in relation to monocropping, due mainly to an increase in $\mathrm{A}$ and the consequent increase in carboxylation efficiency and maintenance of transpiration rates, as shown by the significant correlation between these variables $\left(R=0.899^{\star *}\right.$ for $\mathrm{A}$ and IWUE; and $\mathrm{R}=0.721^{\star *}$ for $\mathrm{A} / \mathrm{Ci}$ and IWUE) (Table 1). Plants usually adopt conservation mechanisms to reduce transpiration and increase carboxylation and water use efficiencies.

Increasing intervals among peanut and castor bean sowings improved yield of the former, the maximum value (1138.32 $\mathrm{kg} \mathrm{ha}^{-1}$ ) being found in peanut plants sown 25 days later (T6), which showed a $96.08 \%$ increase in relation to intercropped plants with no interval between sowings (T2) (Figure 2F). Yield in monocropped plants (T1) (1068.83 $\left.\mathrm{kg} \mathrm{ha}^{-1}\right)$ did not differ statistically $(\mathrm{p}>0.05)$ from intercropped plants with sowing intervals from 10 to 25 days (T3 to T6). However, an $84.12 \%$ reduction was observed in the yield of intercropped castor bean with no interval between sowings (T2) in relation to monocropped plants. 
Regarding yield, the high values observed in intercropped plants with 20 and 25-day intervals between sowings might be the result of a lower interspecific competitiveness of the peanut in relation to the castor bean. Conversely, yield of the intercrop in which species were sown on the same day showed similar results to those found by Cardoso et al. (2013) and Teixeira et al. (2012), all of whom investigated intercropped castor and common beans and found no yield reduction in the former species.

\section{Conclusions}

1. Delaying peanut sowing in an intercropping system with castor bean decreases interspecific competition for soil resources, which has direct effects on the physiology and yield of the latter species.

2. Sowing peanut 20 days after the castor bean increases water use efficiency of the latter species, as its photosynthetic capacity increases while its transpiration remains unaltered.

3. Castor bean yield increases in intercropping system with intervals between sowings ranging from 20 to 25 days, which reinforces the suitability of cultivating castor bean intercropped with peanut in semiarid Brazil.

\section{Literature Cited}

Cardoso, F. R.; Galante, A. H. A.; Teixeira, I. R.; Silva, A. G.; Reis, E. F. Fontes e doses de zinco na nutrição e produção de feijão comum e mamona em consórcio. Revista Brasileira de Ciências Agrárias, v.8, p.602-609, 2013. https://doi.org/10.5039/agraria.v8i4a3417

Dias, D. P.; Marenco, R. A. Fotossíntese e fotoinibição em mogno e acariquara em função da luminosidade e temperatura foliar. Pesquisa Agropecuária Brasileira, v.42, p.305-311, 2007. https:// doi.org/10.1590/S0100-204X2007000300002

EMBRAPA - Empresa Brasileira de Pesquisa Agropecuária. Sistema brasileiro de classificação de solos. 3.ed. Brasília: EMBRAPA 2013. 353p.

Ferraz, R. L. S.; Beltrão, N. E. de M.; Melo, A. S. de; Magalhães, I. D.; Fernandes, P. D.; Rocha, M. do S. Trocas gasosas e eficiência fotoquímica de cultivares de algodoeiro herbáceo sob aplicação de silício foliar. Semina: Ciências Agrárias, v35, p.735-748, 2014.

Ferraz, R. L. S.; Melo, A. S. de; Suassuna, J. F.; Brito, M. E. B.; Fernandes, P. D.; Nunes Júnior, E. S. Trocas gasosas e eficiência fotossintética em ecótipos de feijoeiro cultivados no semiárido. Pesquisa Agropecuária Tropical, v.42, p.181-188, 2012. https:// doi.org/10.1590/S1983-40632012000200010
Jaimez, R. E.; Rada, F.; García-Nuñez, C.; Azocár, A. Seasonal variations in leaf gas exchange of plantain cv. 'Hartón' (Musa $\mathrm{AAB}$ ) under different soil water conditions in a humid tropical region. Scientia Horticulturae, v.104, p.79-89, 2005. https://doi. org/10.1016/j.scienta.2004.07.002

Lithourgidis, A. S.; Dordas, C. A.; Damalas, C. A.; Vlachostergios, A. Annual intercrops: An alternative pathway for sustainable agriculture. Australian Journal of Crop Science, v.5, p.396-410, 2011.

Machado, E. C.; Schmidt, P. T.; Medina, C. L.; Ribeiro, R. V. Respostas da fotossíntese de três espécies de citros a fatores ambientais. Pesquisa Agropecuária Brasileira, v.40, p.1161-1170, 2005. https:// doi.org/10.1590/S0100-204X2005001200002

Melo, A. S. de; Silva Júnior, C. D.; Fernandes, P. D.; Sobral, L. F.; Brito, M. E. B.; Dantas, J. D. M. Alterações das características fisiológicas da bananeira sob condições de fertirrigação. Ciência Rural, v.39, p.733-741, 2009. https://doi.org/10.1590/S010384782008005000101

Paiva, A. S.; Fernandes, E. J.; Rodrigues, T. J. D.; Turco, J. E. P. Condutância estomática em folhas de feijoeiro submetido à diferentes regimes de irrigação. Engenharia Agrícola, v.25, p.161169, 2005. https://doi.org/10.1590/S0100-69162005000100018

Pinto, C. M.; Pitombeira, J. B.; Souza, A. S.; Vidal Neto, F. C.; Távora, F. J. A. F.; Bezerra, A. M. E. Configuração de fileira no consórcio mamona girassol: Produtividade e seus componentes. Revista Brasileira de Ciências Agrárias, v.8, p.33-41 2013. https://doi. org/10.5039/agraria.v8i1a1905

Ribeiro, A. C.; Guimarães, P. T. G.; Alvarez V., V. H. Recomendações para uso de corretivos e fertilizantes em Minas Gerais. 5.ed. Viçosa: UFV, 1999. 142p.

Shimazaki, K. I.; Doi, M.; Assmann, S. M.; Kinoshita, T. Light regulation of stomatal movement. Annual Review of Plant Biology, v.58, p.219-247, 2007. https://doi.org/10.1146/annurev. arplant.57.032905.105434

Silva, M. M. P.; Vasquez, H. M.; Bressansmith, R.; Silva, J. F. C.; Erbesdobler, E. D.; Andrade Júnior, P. S. C. Eficiência fotoquímica de gramíneas forrageiras tropicais submetidas à deficiência hídrica. Revista Brasileira de Zootecnia, v.35, p.67-74, 2006. https://doi.org/10.1590/S1516-35982006000100008

Suassuna, J. F.; Melo, A. S. de; Costa, F. S.; Fernandes, P. D.; Ferreira, R. S.; Sousa, M. S. da S. Eficiência fotoquímica e produtividade de frutos de meloeiro cultivado sob diferentes lâminas de irrigação. Semina: Ciência Agrárias, v.32, p.1251-1262, 2011. https://doi. org/10.5433/1679-0359.2011v32n4p1251

Teixeira, I. R.; Silva, G. C. da; Oliveira, J. A. de P.; Timossi, P. C. Arranjos de plantas do feijoeiro-comum consorciado com mamona. Revista Caatinga, v.25, p.85-91, 2012. 